\title{
Housing market filtering in the Oslo region: pro-market housing policies in a Nordic welfare-state context
}

\author{
Lena Magnusson Turner \\ Norwegian Social Research, Oslo Metropolitan University, Norway \\ Email:1mtu@oslomet.no \\ Terje Wessel \\ Department of Sociology and Human Geography, University of Oslo, Norway \\ Email: terje.wessel@ sosgeo.uio.no
}

\begin{abstract}
Vacancy chain theory suggests that mobility opportunities spread within and between specific states, typically flowing from attractive to less attractive units, with households moving in the opposite direction. We explore whether such welfare gains obtain in a context, the Oslo region, which combines egalitarian welfare programmes and pro-market housing policies. We use merged census and register data from 2011, and include all events that initiate vacancies. Our results show that rental submarkets function poorly. There are many vacancies, but most of them are immediately absorbed by recruits, i.e. households who leave no vacancy behind. Opportunities for disadvantaged groups are further reduced by rapid absorption of owneroccupied flats, often because privileged nest-leavers eschew the rental markets. Two related outcomes are segmentation between submarkets and segregation between Oslo Outer East and the remaining city. All of these adverse consequences reflect the costs of current policies, and call for initiatives that increase and improve opportunities in the rental sector.
\end{abstract}




\section{Introduction}

Numerous recent reports emphasise residential context as an underestimated dimension of socioeconomic status and inequality (Chetty et al., 2014; Galster \& Sharkey, 2017; Sampson, 2013; Sharkey, 2016; Sharkey \& Faber, 2014). It is no longer a question of whether context matters, but rather 'where, when, why, and for whom' it matters (Sharkey \& Faber, 2014, p. $559)$.

One reason why residential context has gained new significance concerns the performance of the housing market. A broad shift towards market-based housing policies has increased the potential for new social divisions, even in countries that once defined housing as a basic human right (Andersson \& Turner, 2014; Tammaru et al., 2015). New divisions may emerge in part because housing construction caters to a privileged section of the public; in part because vacancies in the existing housing stock are terminated; and in part because substandard units remain in the market. The filtering process ${ }^{\mathrm{i}}$, in other words, is key to understanding the distribution and reshaping of housing opportunities.

Our aim in this paper is to explore filtering in a context that combines homeownership and market mechanisms with high levels of public welfare. The Oslo region contains around 80 per cent owner-occupied dwellings (single-family dwellings, condominiums and cooperative apartments), compared to 82 per cent at the national level (Statistics Norway, 2018a). Homeownership is favoured both directly, through tax deductions, and indirectly, through lack of subsidies in the rental sector. This is not a completely new situation, but the implications seem to be amplified year by year. Oslo is one of the fastest growing city-regions in Europe, partly due to a young population and partly due to migration. Flaws and difficulties appear to occur on both sides of the market: suppliers do not respond sufficiently to increasing demand, whereas consumers engage in risky investment activities. The dominating strategy for young households is to head for owner-occupation as soon as possible, even if they incur 
substantial expenses (Wessel, 2015). What makes the situation particularly challenging is the fact that Norway upholds ambitious objectives in the housing sector. The major target for several decades was to obtain a more even distribution of housing than the general distribution of income. Rounds of deregulation have weakened the link between housing and welfare, but there are still public concerns regarding housing affordability, dwelling standards and housing equality. A white paper from 2013, for instance, emphasises that housing consumption should improve general welfare (The Ministry of Local Government and Regional Development, 2013). The ambitions for welfare, in turn, are reflected in great public spending (OECD, 2018) and extensive welfare programmes (Scruggs et al., 2014).

With such a context, one can hardly exaggerate the importance of mobility linkages between submarkets. New housing developments and turnover of existing dwellings ought to produce welfare gains that benefit society at large. The question, of course, is whether the filtering process works in practice. We pursue three related issues: 1) How does the filtering process play out in different submarkets, and to what extent are these submarkets connected through intra-urban mobility? 2) Do vacancies initiated in the Oslo housing market reach groups with a recognised need for housing? 3) Do vacancies spread across districts in a fashion that reduces socio-spatial inequalities? Our understanding of 'recognised needs' is based on government reports and municipal documents that pinpoint, among several groups, young adults who are forced to live in their parental home and recently arrived households without a firm footing in the region (The Ministry of Local Government and Regional Development, 2013). Equally important are groups that, for some reason, remain poor over an extended period of time. These categories do of course overlap - those who enter the market for the first time are often poor. There is nevertheless an important distinction to note: new households of all economic strata terminate the process of filtering. There are no further transactions in the market, since there are no dwellings that can be bought or rented. We 
therefore present the analysis of new households and poor households in different parts of the paper.

The basic premise for our study is that housing vacancies represent opportunities for residential mobility. Each vacancy is part of a chain, i.e. a sequential transfer of vacant dwellings among submarkets, initiated by new construction, out-mobility from the region, and household deaths/dissolution. The approach as a whole emphasises relational aspects of the housing market, which may explain its theoretical and practical importance (Emmi \& Magnusson, 1995; Ferrari, 2011; Nordvik, 2004; Turner, 2008; White, 1970).

Our paper is organised as follows. We begin by a brief review of Norwegian housing policy, with a particular focus on tenure. The next section presents vacancy chain theory, including the mathematical model that undergirds our study. This is followed by a data section, where we set out some definitions and describe the empirical approach. The study relies on merged register and census data, and covers transactions during 2011. We combine housing characteristics into five segments, which are further divided according to location. The subsequent results section shows, in brief, that advantaged and disadvantaged groups have distinctive sets of opportunities, with weak linkages between Western and Eastern submarkets. The rental markets in all parts of the city have a residual character, and cater largely to households that cannot afford homeownership. A more general conclusion is that pro-market housing policies, just like elsewhere, produce uneven outcomes. Egalitarian politics at the national level may compensate for lack of housing options and housing support in many parts of the country, but may struggle to do so in a high-pressure area such as Oslo. Our recommendation, therefore, is that national housing policies should differentiate between areas with different degrees of urban settlement. As for Oslo, the essential task is to strengthen the rental markets. 


\section{Housing policy in Norway}

The housing sector in Norway used to be tightly regulated, e.g. with price ceilings, quantity regulations, rights of first refusal ${ }^{\mathrm{ii}}$ and bans against breakup of co-operative associations. A sweeping reform in 1983-86 removed most of the regulations, and started a gradual withdrawal of supply-side subsidies. As a consequence of these changes, Norway is now practising selective policies in all parts of the housing sector. The overriding concern at the national and local level is to support disadvantaged groups, such as the poor, the youth, the elderly, immigrants and homeless people (Sørvoll, 2011; Wessel, 2015). An indicative element of the policy is that low-income groups may apply for subsidised mortgages ('starter mortgages') that allow them to enter low-priced segments of the owner-occupied market. Most of the state support, however, is provided through the tax system. One estimation suggests that imputed rental income (i.e. tax deductions without counter-weighting tax on capital gains) makes up 11.2 per cent of equivalised disposable income (Bø, 2015), whereas subsidies through the Norwegian State Housing Bank ${ }^{\text {iii }}$ amount to 0.4 per cent (Statistics Norway, 2018b; The Ministry of Finance, 2013). Even the rental markets adapt to these conditions, with a huge number of small landlords, often households, who enter the market for a short period of time. Local governments, by contrast, are largely unwilling/unable to increase the stock of public housing.

What this implies is that most households with low to medium-sized income have to manage the market on their own, or with parental assistance. The share of households who received public economic support in 2011 amounted to 7 per cent of all households (The Norwegian State Housing Bank, 2011). Access to the social rental sector is even more restricted, with 4.3 per cent public housing at the national level and 3.6 per cent in the Oslo region (Statistics Norway, 2018c). 
It is therefore entirely understandable that some researchers place Norway in a liberal version of 'residential capitalism' (Scwartz \& Seabroke, 2008; Stams $\varnothing, 2009)$. There is, nevertheless, a clear discrepancy between Norway and other countries in the same category, such as the United States, the United Kingdom, Canada and Australia. These Englishspeaking countries have more consistent liberal arrangements, with less internal variation and a lower level of welfare spending. Norwegian liberalism in the housing sector cuts across the left-right continuum, and can be traced to widely different influences. Homeownership is undoubtedly rooted in rural mentality, with self-sufficiency as a key virtue (Gullestad, 1989). The liquid market for house mortgages, and the lack of price regulations, on the other hand, are products of the free-market movement of the 1980s. Chicago-school economics loom large behind these latter changes, and even behind the reduced role of the Norwegian State Housing Bank. Some subsidies, however, were removed by a labour government who reluctantly accepted the new situation (Sørvoll, 2011).

Our concept 'pro-market policies' is inspired by the described background. What we refer to is a repertoire of instruments that promotes private housing production, homeownership, free-market transactions and mortgage securitisation. The fact that redistributive aims continue to appear in policy documents (see above) underscores the peculiar combination of influences.

\section{Chains of opportunity - a systems approach to residential mobility}

A prominent stream of housing research explores a minor part of the local housing market, e.g. a sector or a tenure, with scarce attention to the surrounding housing market system (Ferrari, 2011). At the other end, there is also a stream of research that investigates macrolevel outcomes, e.g. house prices or new developments, without illuminating the processes that produce systematic patterns (Smith et al., 2006). Both limitations are frequently recognised in the literature, and have prompted a series of new methodologies: a 'layered 
approach' that places disadvantaged neighbourhoods within a broader metropolitan and regional context (Murie \& Musterd, 2004); a 'pathway approach' that highlights housing practices across time and space (Clapham, 2005); a 'neural network approach' that links housing market values to socioeconomic, demographic and physical determinants (Kauko, 2003); and various agent-based models that demonstrate the link between social dynamics and macro-level properties (Meen \& Meen, 2003).

Several of these approaches provide useful tools for the study of barriers and linkages in urban housing markets. Our preferred choice in the current case, however, is a well-tried approach, vacancy chain theory, which highlights the occurrence of opportunities throughout the market. Using this approach enables us to prioritise supply-side constraints over demandside preferences. In consequence, it also offers insights into the effectiveness of pro-market housing policies.

\section{Vacancy chains}

The idea that resources and positions are distributed through vacancy chains was originally developed in an analysis of organisational mobility (White, 1971), and has later been extended to a large variety of social phenomena: labour markets, housing markets, the development of professions, group discrimination, and organisational demography (Chase, 1991; Spilerman, 1972). Most of the work applies Markov chain models (White, 1970), which are best described as socio-demographic accounting models that simulate the flow of opportunities through a market or a system. A key target for such models is to identify factors at the macro level that create and constrain the opportunity for choice. It is clear, at the same time, that human agency shapes the social impacts of vacancy transfers. The models allow analytical differentiation according to social position, location, preferences or needs, i.e., individuals and families may utilise their resources and pursue their interests as long as the market provides routes for vertical and horizontal mobility. The latter premise is essential, and 
implies that mobility opportunities can be limited or blocked. As noted by Chase (1991), it is not only a question of opportunities as such - the nature of those opportunities is equally important. This point is nicely illustrated in a study of occupational mobility in US labour markets. Harrison (1988) describes how employees in low-paid jobs remain 'stuck at the bottom' due to barriers that surround their current occupations. Similar although weaker degrees of segmentation tend to appear in housing markets. Turner (2008), for instance, shows that chains initiated in the suburbs of Stockholm rarely continue to the city centre, and vice versa.

Markov chain models can be fitted to several types of data, including sequential register data. Equally important, the underlying mechanism, filtering, is a central ingredient in marketbased housing policies. Proponents of such policies frequently emphasise that new dwellings will solve imbalances on the market through two types of effect, first a set of direct effects that fulfil resourceful household's lifestyle dreams, and, second, a set of indirect effects that provide dwellings for economically weak households. The argument builds on the process of 'welfare filtering', which assumes that prices and rents on housing tend to decrease with age; hence, that existing dwellings should have lower costs than new-build dwellings (Skaburskis, 2006). This belief, however, does not necessarily translate into reality. A US study for the period 1975-2011 showed highly variable filtering rates, with lowest rates in the huge owneroccupied market (Rosenthal, 2014). Other researchers emphasise inherent problems in the filtering process, e.g. side-effects that develop over time: 'Even if filtering led to sizeable short-run welfare gains for low-income tenants, the resultant neighbourhood downgrading and abandonment would likely erode these gains seriously in the long run' (Galster, 1996, p. 1803). A somewhat different argument appears in a study of Canadian metropolitan areas. Filtering in Canada, according to Skarburskis (2006), is simply too slow to be part of effective policies for low-income families. 


\section{Formalising the vacancy chain process}

The mathematical model of vacancy transfers builds on the Russian mathematician Andrej Markov's theory of stochastic processes, developed in the early $20^{\text {th }}$ century. A key feature of the model is the conception of transfers as a recurrent, embedded vacancy chain with transient and absorbing states (White, 1970).

In an embedded first-order Markov chain model, only the current position matters for the next step taken by the vacancy. 'Embedded' in this context implies that clock-time, i.e. time spent in a state, is ignored. What counts, instead, is the probability for a vacancy to make a transition from one state to all other states. 'Absorbing' means that all chains will end at one point or another. And as noted, the key units are the vacancies, and not the households.

The application of Markov chain models in housing market analysis raises thorny theoretical and empirical questions. Three of these questions concern basic assumptions in Markov chain theory. The assumption of markovicity presumes that the vacancy lacks 'memory', which implies that a vacancy is transferred from one submarket, here denoted by $i$, to another submarket, here denoted by $j$, without any influence from the previous link. The assumption of homogeneity assumes that the probability of a vacancy to move from submarket $i$ to submarket $j$ is the same in all further divisions of housing submarket $i$. Since there are many attributes to consider (housing size, housing quality, location etc.), the question is whether different nuances affect the accuracy of predictions. The assumption of stationarity assumes that transition probabilities in the Markov chain model are constant over time. The links between housing submarkets are largely a reflection of local demographic, economic and social structures, and since changes in these structures are monotonic rather than cyclical, it may be expected that all parameters in the model change in the same way. As a consequence, one should not stretch the use of Markov chain models over more than four to 
five years. An even shorter period is recommended in situations of economic, social or demographic instability.

The Markov chain model simulates the inter-sectoral transfer and absorption of vacant housing opportunities as a function of vacancy creations (Emmi \& Magnusson, 1994; Magnusson, 1994). The model is based on accounting equation (1), which says that the total number of vacancy transfers in each state (n') equals those that are transferred to it from other states (' $\mathbf{N}^{\mathbf{T}}$ ) plus those added at its margin by vacancy creating events ( $\left.\mathbf{n}_{\mathbf{c}}{ }^{\prime}\right)$. In the following equations, the sign' indicates a row. The law of motion of vacancies is then given by:

$\mathbf{n}^{\prime}=\mathbf{1}^{\prime} \mathbf{N}^{\mathbf{T}}+\mathbf{n}_{\mathbf{c}}{ }^{\prime}$

where $\mathbf{n}$ is a $K \times 1$ vector of vacant houses and apartments, and $K$ is the number of states. The matrix $\mathbf{N}$ has dimension $K \times K$ and measures the flow of vacancies between the $K$ states. The number 1 represents a $K \times 1$ vector of ones. Thus, the $k^{\text {th }}$ element of $\mathbf{1}^{\prime} \mathbf{N}$ are vacancies in state $i$ coming from other states plus itself. Finally, $\mathbf{n}_{\mathbf{c}}$ is a $K \times 1$ matrix of vacancies arising from new construction, out-mobility and household deaths.

The accounting statement can be developed into an analytical model by using intersectoral vacancy transfer probabilities under the conditions explained above. With the assumptions of (1) homogeneity, (2) stationarity and (3) markovicity, a matrix of vacancy transition probabilities (P) can be introduced. Here, in equation (2), we identify the probability of a vacancy in a specific state to be transferred to all other states. Let $\mathbf{P}$ denote the $K \times K$ matrix of transition probabilities, where element $i, j$ is the probability that a vacancy in state $i$ leads to a vacancy in state $j$. The model can be written as:

$\mathbf{n}^{\prime}=\mathbf{n}^{\prime} \mathbf{P}+\mathbf{n}_{\mathbf{c}}{ }^{\prime}$

While this model offers analytical tractability, it fails to isolate the total volume of transfers (n) to one side of the equation. To solve the problem, i.e. to find the unknown vector, we may 
employ two equivalent methods - either a power expansion series or a matrix inversion, which can be expressed as follows:

$\mathbf{n}^{\prime}=\mathbf{n}_{\mathbf{c}}(\mathbf{I}+\mathbf{P}+\mathbf{P} 2+\mathbf{P 3}+\ldots)=\mathbf{n c}^{\prime}(\mathbf{I}-\mathbf{P})-\mathbf{1}=\mathbf{n c}^{\prime} \mathbf{M}$

Equation (3) simulates the vacancy chain process by determining the probabilities of going from state $i$ to state $j$ in one, two and three or more steps, and then taking the sum of these probabilities. This sum of the accumulating but ever declining probabilities of successive transfers defines a new matrix $\mathbf{M}$, which is denoted 'the Markov multiplier matrix' of a vacancy chain. Its elements define the expected fractional number of times a vacancy initiated in any state $i$ ever visits any state $j$ before absorption. The row sums (m) of the Markov multiplier matrix define state-specific vacancy chain lengths - the number of dwelling units involved in the vacancy chains initiated by vacancy creations in state $i$ :

$\mathbf{m}=\mathbf{M} * \mathbf{1}$

Newly created housing opportunities induce a chain of vacancy transfers that are captured by the Markov multiplier matrix. These opportunities, plus the absorption probabilities, define the expected number of vacancies transferred to each absorbing state (the subscript a), based on a vector-to-diagonal transformation (the subscript $\mathrm{dg}$ ):

$\mathbf{n}_{\mathbf{a}}{ }^{\prime}=\mathbf{n}_{\mathbf{c}}{ }^{\prime} \mathbf{M}\left(\mathbf{p}_{\mathbf{a}}\right)_{\mathbf{d g}}$

To summarise, the vacancy chain model simulates the transfers of vacant housing opportunities among housing sectors, in response to either the initiation of new opportunities or absorption of existing ones (see Figure 1). The possibility to explore residential mobility among households is a by-product of the model. 


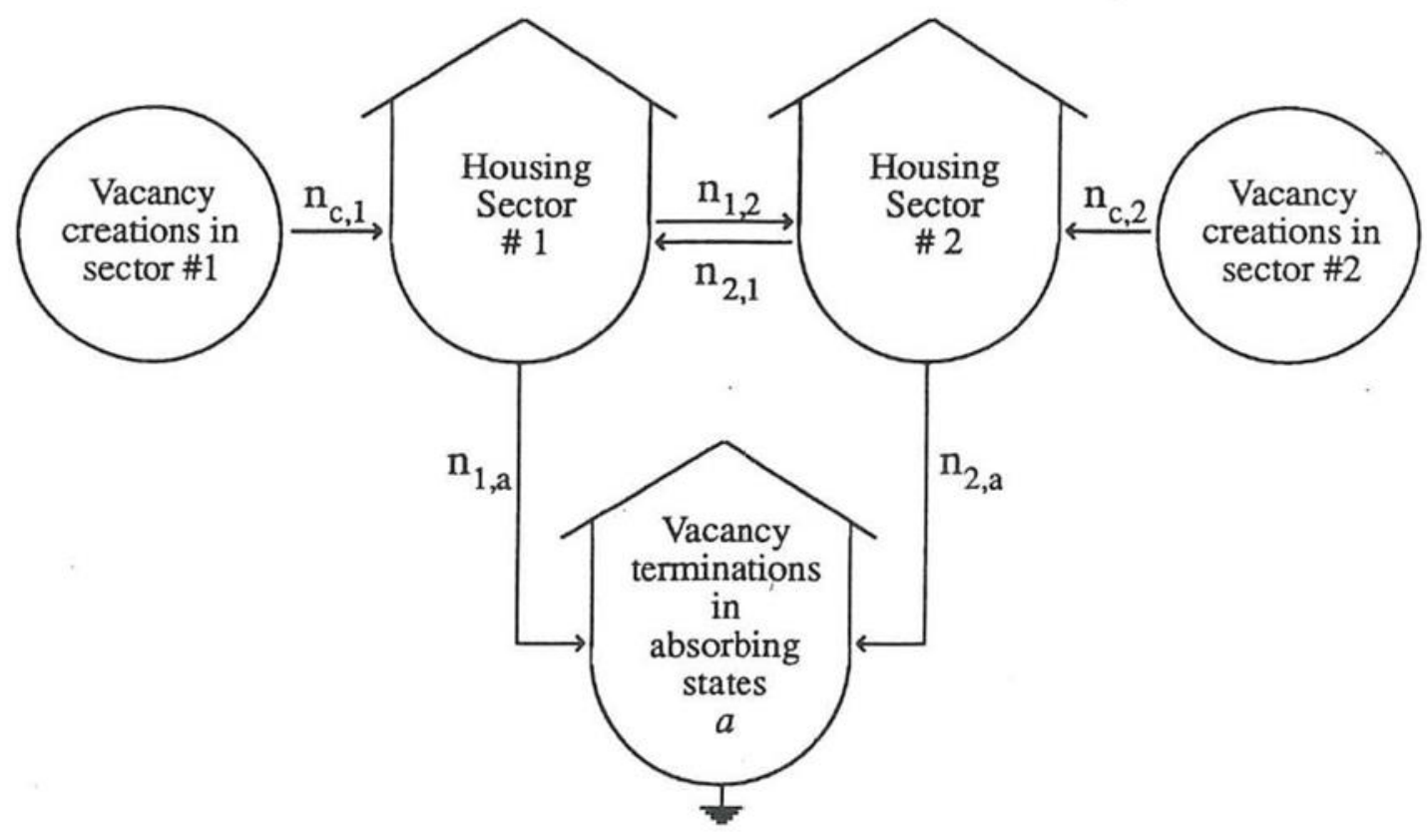

Figure 1. Schematic illustration of the vacancy transfer process in a housing market with two housing sectors. Source: Emmi \& Magnusson (1995, page 24)

\section{Data and definitions}

We use a unique longitudinal database with annual economic, demographic and geographic information for all individuals. The data were gathered from several national registers under the control of Statistics Norway, the Directorate of Taxes, the Norwegian Labour and Welfare Administration and other national authorities. Most variables refer to individuals, but we also employ some household variables that allow us to analyse how submarkets are interconnected through residential mobility. We follow Statistics Norway's classification of head of household and select the oldest person in each multi-person household as reference person for the analyses. Our research area, the Oslo region, includes the core municipality plus 18 surrounding municipalities with more than 25 per cent commuting to the core municipality (see Juvkam, 2000). We sometimes refer to this area as the 'Oslo housing market'.

An essential issue in the study is the definition of submarkets (i.e. the states in the formal model). As noted, these units have to be defined in accordance with the homogeneity 
principle. While many dwelling attributes are relevant (see Watkins, 2001), one cannot include more than a few in a single analysis. ${ }^{\text {iv }}$ The ones we have chosen are: 1) type of building, 2) type of owner, and 3) geographical location. Information on number of rooms is also available but is less useful due to a significant number of missing observations. ${ }^{v}$ We limit our analysis to the latest census year, 2011, and link information for two dates - January 1 (register data) and November 19 (census data). ${ }^{\mathrm{vi}}$

Following White (1971) and Hua (1989), we calibrate the Markov chain model by identifying the entire volume of events that may initiate a vacancy. We further include all household moves between housing states during the period, plus all events that absorb vacancies. Hence, the total vacancy creations and absorptions ought to balance, but not the state-specific rates. Usually, a vacancy initiated in one state has a high probability of being absorbed in another state. But a basic prerequisite for the model is that the sum of vacancy transfers and vacancy initiations equals the sum of vacancy transfers and vacancy absorptions for each state.

The empirical strategy can be divided into three steps. We first select significant sectoral divisions in the Oslo housing market. Here, we follow the common practices and include cooperative ownership under owner-occupancy. We also merge detached and semidetached houses into one group, single-family houses, which we contrast to flats in multifamily houses (see Nordvik \& Osland, 2017). Another group, 'other dwellings', consists of temporary dwellings (e.g. summerhouses), combined buildings (e.g. combined dwelling and business buildings) and student housing. We thus explore five sectoral categories:

- Single-family houses, owned

- Single-family houses, rental

- Flats, owned

- Flats, rental 
- Other dwellings (owned or rental)

We then define absorbing states, i.e. states where the vacancies meet an end. Absorption in our study occurs when four subgroups - nest-leavers, new adults, in-movers or immigrants - acquire a vacant dwelling. 'Nest-leavers' lived in the parental home in Oslo at the start of 2011 and moved to another dwelling in Oslo in the same year. 'New adults' lived in Oslo as married or registered partners at the start of 2011 and moved to a separate dwelling within the region after a divorce in the same year. 'In-movers' were registered in a different region in Norway at the start of 2011 and entered Oslo in the same year. 'Immigrants' (including refugees) arrived in Oslo at some point during 2011, without intermediate settlement elsewhere in Norway. Finally, we also refer to 'recruits' as an umbrella term for the four groups.

The final step is to identify vacancies. Here, we separate between three types of supply: 1) vacancies initiated by new construction during 2011, labelled 'ADD’N' (9 per cent), 2) vacancies initiated by out-mobility from Oslo between January 1 and November 19, 2011 (both moves within Norway and emigration) (total: 57 per cent), and 3) vacancies initiated by household deaths and household dissolutions (total: 34 per cent). The latter category consists primarily of individuals who were singles at the start of 2011, and who moved to establish new households as married/ cohabitant in the same year. To avoid clutter, we do not report separate results for household changes, deaths and relocations. Instead, we subsume all these events under the term 'EXITS'. 

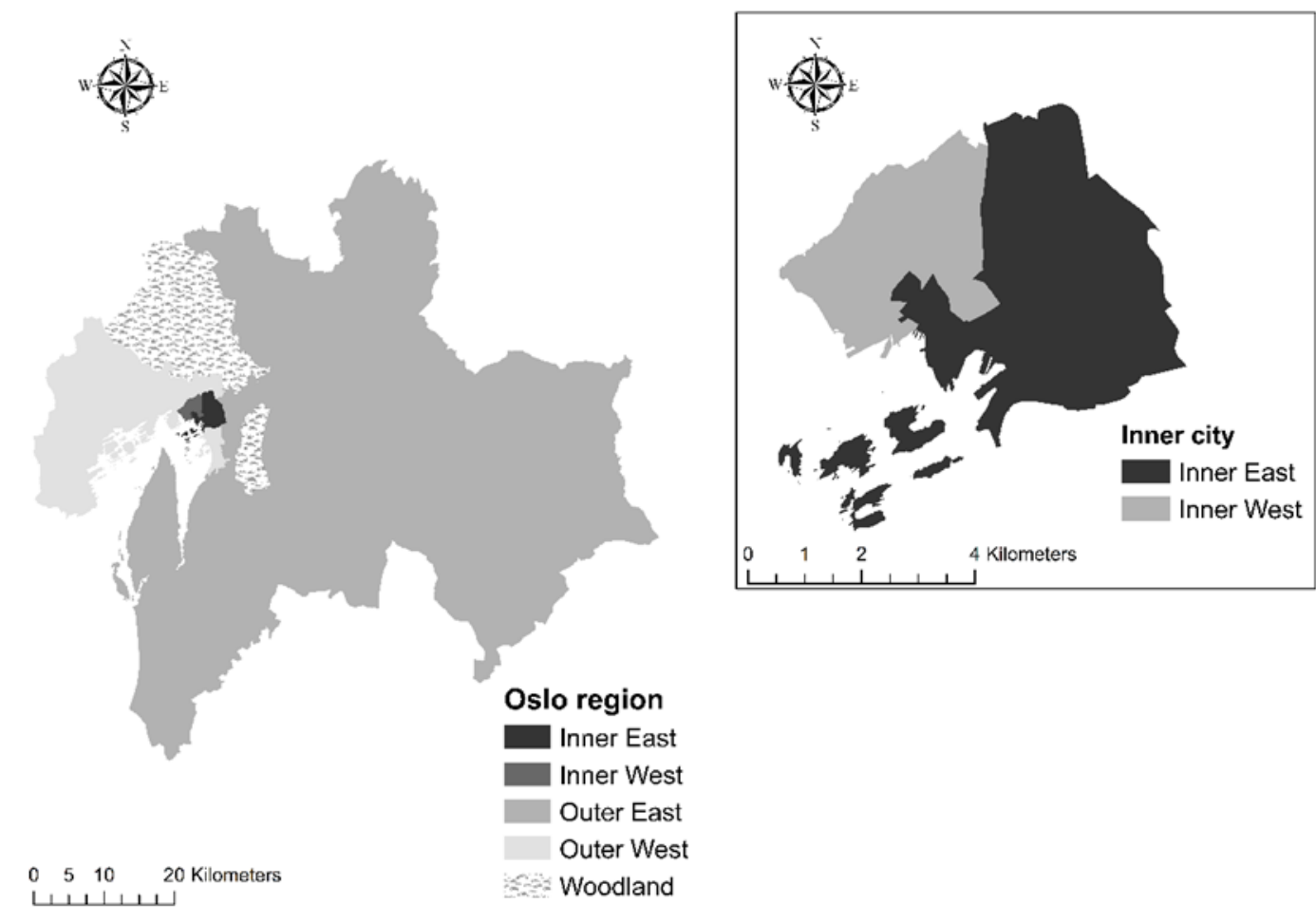

Figure 2. Oslo region and Inner city. Maps by the authors.

Our analysis of socio-spatial patterns applies two dichotomies - one between the inner and the outer city, and one between East and West. The detailed division (see Figure 2) is based on a combination of neighbourhood borders, township borders and municipality borders:

- Inner East: Township 1-3 plus the downtown area in the municipality of Oslo.

- Inner West: Township 4-5 in the municipality of Oslo, except neighbourhood 51 in township 5.

- Outer East: Township 9-13, a small part of 14 (neighbourhood 145) and 15 in the municipality of Oslo, plus municipality 211-217 and 221-235 in the surrounding hinterland. 
- Outer West: Neighbourhood 51 in township 5, township 6-8 and the larger part of 14 (minus neighbourhood 145) in the municipality of Oslo, plus municipality 219 and 220 in the surrounding hinterland.

The East-West border has existed since the $19^{\text {th }}$ century, and represents a classic demarcation line: East is the less affluent and West the more affluent area. A recent study of house price levels shows the following ranking: 1) Inner West, 2) Outer West, 3) Inner East, 4) Outer East. The difference between Inner West and Outer East reaches up to 60 percentage points for similar dwellings (Barlindhaug, 2017).

As a follow-up, we also explore differences between poor and non-poor households, using income after tax per consumption unit (EU-scale) as the classification variable. This analysis combines location, type of building and tenure, although with less information regarding geographical links and absorbing states.

\section{Limitations and caveats}

The quality of the data is generally high. We have excellent information regarding internal mobility, emigration, deaths and income. There is one weakness though: some newly formed couples are bound to be absent from the register.

We use the study as a basis for crude policy assessments, even though we lack a contrasting case. This practice is well-established in vacancy chain research, and is motivated by the correspondence between policy and outcome: any filtering policy ought to produce substantial filtering; otherwise, the policy is not very effective. Our ideal design, of course, would be to explore variation across time or space.

\section{Major patterns}

About 32,500 vacancies (sum of ADD'N and EXITS) and 76,200 vacancy transfers (sum of all transfer states) were initiated on the Oslo housing market during the observation period 
(Table 1). Average number of transfers per vacancy is thus 2.3 , which is short for a study that covers the entire housing stock (see Chase, 1991; Turner, 2008; Marullo, 1985). The distribution across submarkets is highly skewed, with 53 per cent of all vacancies occurring in the marginal rental sector.

Looking at transfers (Table 2), we first note that all vacancies are finally absorbed through new occupation. This happens immediately in 43 per cent of the cases, which roughly accords with previous research (Ferrari, 2011; Lévy et al., 2016; Turner, 2008). Oslo deviates, however, in the variation across submarkets. Many Western cities have at least one rental submarket that generates substantial local filtering. Stockholm, as an example, has a low degree of immediate absorption in rental multi-family houses (below 30 per cent), whether they are privately or publicly owned (Turner, 2008). Similar results appear in an older study from Southern parts of Sweden (Skåne) (Clark, 1984). What we find in Oslo is a rental sector where most vacancies are immediately absorbed, with little difference between flats and single-family houses. Owner occupation, by contrast, is marked by local filtering, as we may see from column 11 of Table 2. Vacancies in owner occupation generate transfers across the tenure divide, whereas vacancies in rental markets have minimal implications for turnover in owner occupation. These differences obtain for both flats and single-family houses, but there is also a marked interaction between building type and tenure. The largest probability of transfer, including transfer between submarkets, appears for owner-occupied single-family houses. Single-family houses that are rented, by comparison, have the lowest probability of transfer. This segment generates less internal circulation than rental flats, and attracts few households from owner-occupied housing.

A further differentiation shows that nest-leaving (Table 2, column 6) represents the most important type of absorption, followed by immigration. These two groups appear to compete 
Table 1. Absolute number of vacancy transfers in 2011, by ownership and building type

\begin{tabular}{|c|c|c|c|c|c|c|c|c|c|c|}
\hline \multirow[b]{3}{*}{ ORIGIN } & \multicolumn{9}{|c|}{ DESTINATION } & \multirow{3}{*}{ TOTAL } \\
\hline & \multicolumn{5}{|c|}{ Transfer states } & \multicolumn{4}{|c|}{ Absorbing states } & \\
\hline & $\begin{array}{l}\text { Single family } \\
\text { house, owned }\end{array}$ & $\begin{array}{l}\text { Single family } \\
\text { house, rental }\end{array}$ & $\begin{array}{l}\text { Flat, } \\
\text { owned }\end{array}$ & $\begin{array}{l}\text { Flat, } \\
\text { rental }\end{array}$ & $\begin{array}{c}\text { Other } \\
\text { dwellings }\end{array}$ & $\begin{array}{l}\text { Nest- } \\
\text { leaver }\end{array}$ & Immigrant & In-mover & $\begin{array}{l}\text { New } \\
\text { adult }\end{array}$ & \\
\hline Single family house, owned & 3455 & 1484 & 3718 & 1196 & 236 & 458 & 1046 & 960 & 669 & 13222 \\
\hline Single family house, rental & 269 & 2297 & 218 & 1872 & 317 & 1718 & 1992 & 1054 & 774 & 10511 \\
\hline Flat, owned & 2760 & 951 & 7208 & 2789 & 340 & 3695 & 140 & 1745 & 1534 & 22362 \\
\hline Flat, rental & 247 & 2378 & 735 & 9005 & 685 & 5657 & 4333 & 2266 & 1743 & 27049 \\
\hline Other dwellings & 92 & 431 & 91 & 696 & 232 & 540 & 541 & 226 & 198 & 3047 \\
\hline EXITS & 5210 & 2633 & 9562 & 11141 & 1165 & & & & & 29711 \\
\hline ADD'N & 1189 & 337 & 830 & 350 & 72 & & & & & 2778 \\
\hline TOTAL & 13222 & 10511 & 22362 & 27049 & 3047 & 12068 & 9252 & 6251 & 4918 & \\
\hline
\end{tabular}

Table 2. Vacancy transaction and absorption probabilities $\left(\mathrm{P}: \mathrm{P}^{\mathrm{a}}\right)$

\begin{tabular}{|c|c|c|c|c|c|c|c|c|c|c|c|c|}
\hline \multirow[b]{3}{*}{ ORIGIN } & \multicolumn{10}{|c|}{ DESTINATION } & \multirow{2}{*}{\multicolumn{2}{|c|}{ Sum of probabilities }} \\
\hline & \multicolumn{5}{|c|}{ Transfer states } & \multicolumn{4}{|c|}{ Absorbing states } & \multirow[t]{2}{*}{ TOTAL } & & \\
\hline & $\begin{array}{l}\text { Single-family } \\
\text { house, owned }\end{array}$ & $\begin{array}{l}\text { Single-family } \\
\text { house, rental }\end{array}$ & $\begin{array}{c}\text { Flat, } \\
\text { owned }\end{array}$ & $\begin{array}{l}\text { Flat, } \\
\text { rental }\end{array}$ & $\begin{array}{c}\text { Other } \\
\text { dwellings }\end{array}$ & $\begin{array}{c}\text { Nest } \\
\text { leaver }\end{array}$ & $\begin{array}{l}\text { Immi- } \\
\text { grant }\end{array}$ & $\begin{array}{c}\text { In- } \\
\text { mover }\end{array}$ & $\begin{array}{l}\text { New } \\
\text { adult }\end{array}$ & & Transfer & Absorption \\
\hline Single-family house, owned & 0.26 & 0.11 & 0.28 & 0.09 & 0.02 & 0.03 & 0.08 & 0.07 & 0.05 & 1.00 & 0.76 & 0.24 \\
\hline Single-family house, rental & 0.03 & 0.22 & 0.02 & 0.18 & 0.03 & 0.16 & 0.19 & 0.10 & 0.07 & 1.00 & 0.47 & 0.53 \\
\hline Flat, owned & 0.12 & 0.04 & 0.32 & 0.12 & 0.02 & 0.17 & 0.06 & 0.08 & 0.07 & 1.00 & 0.63 & 0.37 \\
\hline Flat, rental & 0.01 & 0.09 & 0.03 & 0.33 & 0.03 & 0.21 & 0.16 & 0.08 & 0.06 & 1.00 & 0.48 & 0.52 \\
\hline Other dwellings & 0.03 & 0.14 & 0.03 & 0.23 & 0.08 & 0.18 & 0.18 & 0.07 & 0.06 & 1.00 & 0.51 & 0.49 \\
\hline TOTAL & 0.09 & 0.10 & 0.16 & 0.20 & 0.02 & 0.16 & 0.12 & 0.08 & 0.06 & 1.00 & 0.57 & 0.43 \\
\hline
\end{tabular}


for the same type of housing, although with one exception: nest-leavers terminate many vacancies in owner-occupied flats. This is a fairly clear indication of family influences in the Oslo housing market, in line with previous research (Gulbrandsen \& Langsether, 2003). The last two groups, in-movers and new adults, have fairly equal absorption rates across different submarkets.

We may summarise these results in two points. First, rental markets in Oslo are characterised by intense transaction activity within a small part of the housing stock. One tangible indicator in this respect is the average length of residence, which lies around 3.0 years, compared to 9.8 years in owner-occupied markets. ${ }^{7}$ Second, the intense activity has minor implications for well-established households in the region. A tenure form with limited access to subsidies and considerable insecurity is, unsurprisingly, dismissed by the broader public. The fact that immigrants and nest-leavers absorb 35-37 per cent of rental vacancies underscores the marginal character of such housing.

Table 3 shows the Markov multiplier matrix for all submarkets. Average chain length is lowest for vacancies that arise in the rental markets, with minimal difference between flats (1.98) and single-family houses (1.97). The longest chain obtains when vacancies begin in owner-occupied single-family houses (2.91), in line with patterns in a 1980-survey (Bysveen $\&$ Knutsen, 1987). Owner-occupied single-family houses represent the top of the local hierarchy, and have a strong link to the market for owner-occupied flats (vacancy multiplier = 0.64). This suggests a certain degree of filtering, i.e. downward flows in terms of house price or income. We should add, though, that owner-occupied flats come in all shapes and sizes some are small, some are large, some are low-priced, some are high-priced, etc. Those who prefer and can afford urban living have many products to select from, and may opt for a comfortable apartment instead of a house. The opposite applies as well - those who prefer a suburban lifestyle can advance to the top through intermediate steps in multi-family houses. It 
is therefore fully comprehensible that vacant flats, independent of tenure, generate considerable internal turnover (Table 3, column 3).

Table 2. Markov multiplier matrix $\left(M=\sum P^{n}\right)$ and vacancy chain length $\left(m=M^{*} 1\right)$

\begin{tabular}{lcccccc}
\hline & \multicolumn{3}{c}{ DESTINATION } & & \\
\hline ORIGIN & $\begin{array}{c}\text { Single-family } \\
\text { house, owned }\end{array}$ & $\begin{array}{c}\text { Single-family } \\
\text { house, rental }\end{array}$ & $\begin{array}{c}\text { Flat, } \\
\text { owned }\end{array}$ & $\begin{array}{c}\text { Flat, } \\
\text { rental }\end{array}$ & $\begin{array}{c}\text { Other } \\
\text { dwellings }\end{array}$ & TOTAL \\
\hline Single-family house, owned & 1.48 & 0.31 & 0.64 & 0.42 & 0.06 & 2.91 \\
Single-family house, rental & 0.07 & 1.35 & 0.09 & 0.41 & 0.06 & 1.97 \\
Flat, owned & 0.28 & 0.18 & 1.62 & 0.41 & 0.05 & 2.54 \\
Flat, rental & 0.04 & 0.20 & 0.09 & 1.59 & 0.05 & 1.98 \\
Other dwellings & 0.08 & 0.27 & 0.11 & 0.48 & 1.11 & 2.05 \\
\hline
\end{tabular}

Next, we turn to spatial variations. Table 4 summarises transfers and immediate absorptions across the four subareas. The results show, firstly, that below 15 per cent of the vacancies that emerge in the inner city travel to the outer city, a pattern that corresponds closely to the variation between flats and single-family houses in Table 2 . Filtering in the inner city is obviously affected by the housing structure and the relative ranking of different areas. Equally important, inner-city areas offer environments, both housing, educational institutions and facilities (e.g. libraries, theatres, galleries, pubs and restaurants), that attract recruits on the market (see Table 4, column 5).

A second point is that transition probabilities differ between East and West. The share of transfers is lower in the affluent West, and higher in the poorer East. The explanation for this pattern cannot be housing structure, since there are more single-family houses in Outer West than in Outer East, nor the existence of institutions and urban facilities, since Inner West has a plethora of schools, university departments and cultural institutions. A more sensible explanation is that Western areas, particularly Outer West, attract numerous labour migrants from Poland and the Baltics. These groups converge towards areas where private households are able to pay for building maintenance and domestic services (Wessel et al., 2018). An 
additional factor for Inner West is financial support from the family. We cannot measure this factor directly, but it looms large in the background when 23 per cent of all vacancies in the highest-priced area are taken by nest-leavers.

Third, and most important, Table 4 clearly demonstrates the separation between East and West. There is some connection between Inner East and Inner West, but not a lot between Outer East and Outer West. Just 6 per cent of all vacancies in Outer East generate transfers in Outer West, with similar spill-over eastward. 
Table 4. Vacancy transition probabilities $\left(\mathrm{P}: \mathrm{P}^{\mathrm{a}}\right)$, geographical location

\begin{tabular}{|c|c|c|c|c|c|c|c|c|c|c|c|}
\hline \multirow[b]{3}{*}{ ORIGIN } & \multicolumn{9}{|c|}{ DESTINATION } & \multirow{2}{*}{\multicolumn{2}{|c|}{ Sum of probabilities }} \\
\hline & \multicolumn{4}{|c|}{ Transfer states } & \multicolumn{4}{|c|}{ Absorbing states } & \multirow[t]{2}{*}{ TOTAL } & & \\
\hline & Inner East & $\begin{array}{l}\text { Inner } \\
\text { West }\end{array}$ & $\begin{array}{c}\text { Outer } \\
\text { East }\end{array}$ & $\begin{array}{l}\text { Outer } \\
\text { West }\end{array}$ & $\begin{array}{l}\text { Nest } \\
\text { leaver }\end{array}$ & $\begin{array}{l}\text { Immi- } \\
\text { grant }\end{array}$ & $\begin{array}{c}\text { In- } \\
\text { mover }\end{array}$ & $\begin{array}{l}\text { New } \\
\text { Adult }\end{array}$ & & Transfer & Absorption \\
\hline Inner East & 0.28 & 0.11 & 0.08 & 0.06 & 0.20 & 0.12 & 0.08 & 0.06 & 1.00 & 0.53 & 0.47 \\
\hline Inner West & 0.11 & 0.25 & 0.05 & 0.08 & 0.23 & 0.15 & 0.08 & 0.06 & 1.00 & 0.48 & 0.52 \\
\hline Outer East & 0.08 & 0.03 & 0.46 & 0.06 & 0.11 & 0.12 & 0.08 & 0.07 & 1.00 & 0.63 & 0.37 \\
\hline Outer West & 0.08 & 0.08 & 0.06 & 0.37 & 0.11 & 0.16 & 0.09 & 0.06 & 1.00 & 0.59 & 0.41 \\
\hline TOTAL & 0.13 & 0,10 & 0.20 & 0.14 & 0.15 & 0.13 & 0.08 & 0.06 & 1.00 & 0.57 & 0.43 \\
\hline
\end{tabular}

Table 5. Markov multiplier matrix $\left(M=\sum P^{n}\right)$ and vacancy chain length $\left(m=M^{*} 1\right)$, geographical location

\begin{tabular}{|c|c|c|c|c|c|c|}
\hline \multicolumn{6}{|c|}{ DESTINATION } & \multirow{2}{*}{$\frac{\text { Ratio }}{\text { Transfer between }}$} \\
\hline ORIGIN & Inner East & Inner & Outer & Outer & TOTAL & \\
\hline & & West & East & West & & East and West \\
\hline Inner East & 1.47 & 0.25 & 0.25 & 0.20 & 2.17 & 0.21 \\
\hline Inner West & 0.25 & 1.40 & 0.18 & 0.22 & 2.05 & 0.20 \\
\hline Outer East & 0.27 & 0.15 & 1.91 & 0.21 & 2.54 & 0.14 \\
\hline Outer West & 0.24 & 0.23 & 0.24 & 1.65 & 2.37 & 0.20 \\
\hline
\end{tabular}


The picture of a segmented market is equally clear when we summarise multiplier effects (Table 5). Vacancy chains tend to remain in each part of the region, although with some differentiation between inner-city and outer-city areas. An interesting detail is that Outer West displays a relatively strong link to Inner East, whereas Outer East lacks a similar link to Inner West. This asymmetry has arisen over the last decades (see Bysveen \& Knutsen, 1987), and is obviously explained by gentrification. Many neighbourhoods in Inner East have become gentrified, but continue to experience low population stability. The housing structure of this area does not promote large-scale family gentrification, nor gentrification of original gentrifiers ('super-gentrification'). What we see, therefore, is a large flow in the Western direction.

\section{Opportunities for poor households}

Our analysis of vacancy transfers across housing categories and locations suggests a large potential for price variation, where suppliers target distinct types of households. To demonstrate this, we will now extend the analysis to population subgroups, using separate Markov matrixes for poor and non-poor households. We further differentiate between intraurban movers, which correspond to transfer states, and recruits, which correspond to absorbing states. 
Table 5. Vacancy chains disaggregated by poverty status and type of movement

\begin{tabular}{|c|c|c|c|c|c|c|c|}
\hline \multirow[t]{2}{*}{ ORIGIN } & \multicolumn{2}{|c|}{ Intra-urban movers } & \multicolumn{2}{|c|}{ Recruits } & \multirow{2}{*}{$\begin{array}{l}\text { Mean } \\
\text { length }\end{array}$} & \multirow{2}{*}{$\begin{array}{c}\text { Share of } \\
\text { moves }\end{array}$} & \multirow{2}{*}{$\begin{array}{l}\text { Ratio } \\
\text { poor }\end{array}$} \\
\hline & Poor & Non-poor & Poor & Non-poor & & & \\
\hline \multicolumn{8}{|c|}{ Single family house, owned } \\
\hline Inner East & 0.19 & 1.55 & 0.25 & 0.57 & 2.56 & 0.00 & 0.18 \\
\hline Inner West & 0.30 & 1.84 & 0.28 & 0.38 & 2.80 & 0.00 & 0.21 \\
\hline Outer East & 0.17 & 2.08 & 0.21 & 0.47 & 2.94 & 0.10 & 0.13 \\
\hline Outer West & 0.15 & 2.05 & 0.21 & 0.47 & 2.87 & 0.07 & 0.12 \\
\hline \multicolumn{8}{|l|}{ Flat, owned } \\
\hline Inner East & 0.15 & 1.21 & 0.26 & 0.71 & 2.33 & 0.09 & 0.17 \\
\hline Inner West & 0.16 & 1.15 & 0.31 & 0.68 & 2.30 & 0.05 & 0.20 \\
\hline Outer East & 0.18 & 1.63 & 0.21 & 0.67 & 2.68 & 0.09 & 0.15 \\
\hline Outer West & 0.10 & 1.72 & 0.17 & 0.70 & 2.69 & 0.05 & 0.10 \\
\hline \multicolumn{8}{|c|}{ Single family house, rental } \\
\hline Inner East & 0.27 & 0.56 & 0.61 & 0.43 & 1.87 & 0.00 & 0.47 \\
\hline Inner West & 0.32 & 0.56 & 0.56 & 0.46 & 1.90 & 0.00 & 0.47 \\
\hline Outer East & 0.27 & 0.72 & 0.61 & 0.43 & 2.04 & 0.07 & 0.43 \\
\hline Outer West & 0.26 & 0.59 & 0.60 & 0.44 & 1.89 & 0.06 & 0.46 \\
\hline \multicolumn{8}{|l|}{ Flat, rental } \\
\hline Inner East & 0.32 & 0.66 & 0.53 & 0.47 & 1.98 & 0.13 & 0.43 \\
\hline Inner West & 0.25 & 0.55 & 0.56 & 0.49 & 1.85 & 0.12 & 0.43 \\
\hline Outer East & 0.37 & 0.80 & 0.59 & 0.39 & 2.15 & 0.06 & 0.44 \\
\hline Outer West & 0.29 & 0.65 & 0.66 & 0.37 & 1.97 & 0.05 & 0.49 \\
\hline \multicolumn{8}{|c|}{ Other dwellings } \\
\hline Inner East & 0.50 & 0.47 & 0.72 & 0.28 & 1.97 & 0.01 & 0.61 \\
\hline Inner West & 0.30 & 0.45 & 0.70 & 0.37 & 1.82 & 0.00 & 0.54 \\
\hline Outer East & 0.30 & 0.95 & 0.51 & 0.48 & 2.24 & 0.01 & 0.37 \\
\hline Outer West & 0.40 & 0.55 & 0.76 & 0.26 & 1.97 & 0.01 & 0.59 \\
\hline Total & 0.19 & 0.81 & 0.47 & 0.53 & 2.24 & 1.00 & 0.31 \\
\hline
\end{tabular}

Table 6 shows that poor households make up 19 per cent of intra-urban movers and 47 per cent of all recruits. Both groups depend heavily on rental vacancies, but they spread differently in space. The former group is largely confined to Oslo East, particularly Outer East. The latter group seizes opportunities in all parts of the city, including Inner West. Indeed, looking at owner-occupied housing, we may even conclude that Inner West is the hottest area for low-income recruits (column 7). Outer East, in contrast, is the least popular area, particularly if we consider the number of vacancies in each area (Table 1). The pattern as a whole seems strange, if not downright 'perverse', but it becomes logical when we 
separate nest-leavers from other recruits. We have already seen that nest-leavers have an affinity for Inner West (Table 4). Many individuals in this group are poor, and dominate among poor recruits in owner-occupied markets. ${ }^{8}$

Low income is thus an imprecise indicator in the current context. Some households qualify as 'poor' according to formal definitions, but their housing situation is far from desperate. Access to family resources allows them to enter the owner-occupied market, from which they can safely climb the housing ladder. Other households are poor in the real sense they lack both income and assets, and compete for housing in a dysfunctional rental market. Our data and design prevent a rich description of these differences, but we do sense that poor intra-urban movers have additional challenges compared to poor recruits. A relevant example is the propensity to acquire rental flats in Outer East, which is 16 per cent higher in the former group.

It is equally clear that recruits without roots in Oslo face difficult competition from local residents. This applies both to immigrants and to non-local natives.

\section{Conclusion and discussion}

Overall, the results in this study underscore the challenges to housing policies that depend heavily on market forces. A large number of disadvantaged households obtain no public support, and have to rely on opportunities that emerge through vacancy chain mobility. The problem is, firstly, that rental submarkets function poorly. More than half of all vacated dwellings in these submarkets are occupied by recruits who leave no vacancy for others to fill. A large part of the remaining supply is subject to intense competition among households who search for a new short-term tenancy. There is no lack of action in the system, but the many contacts and transfers appear to have little impact on internal structures and market products. What we sense, instead, is that tenants either adapt through a mobile lifestyle or rush towards 
homeownership. And, importantly, once people have left the rental market, there is very little chance of return.

A second and related problem concerns recruitment. More than 30 per cent of all nestleavers sidestep the malfunctioning rental market, and move directly into homeownership. This implies, from a social policy perspective, that recruits and intra-urban movers who lack family support face higher costs of homeownership. Obviously, they also lag behind in the formation of housing wealth. One might argue that early entry to homeownership is a highrisk strategy. The real estate market in Oslo, however, is rather 'different'. A combination of population growth and economic growth has led to more or less continuous house price increases ever since 1992. We may therefore safely assume that nest-leavers who entered homeownership in 2011 gained a significant advantage compared to counterparts who acquired a rental dwelling, given that house prices grew by 55 per cent between 2011 and 2017 (Statistics Norway, 2018e).

A third problem is that owner-occupied markets generate few opportunities for poor intra-urban movers. Poor recruits are slightly better off, largely due to the pattern among nestleavers . In general, we are not able to detect significant trickle-down effects, partly due to short chains and partly due to closure between segments.

Finally, we also identify a poor connection between Outer East and the remaining city. Vacancies in Outer East produce a great deal of internal circulation, but not a lot in the Western districts and less than expected in Inner East. The opposite applies as well: new opportunities in West, and to some extent Inner East, have minor implications for market activity in Outer East. Inner East plays a bridging role between East and West, with vacancies moving in both directions. Inner East, however, represents less than a fourth of all vacancies, and exposes residents to a landscape with different attributes than Outer East. It is not implausible that gentrification and increasing diversity in Inner East is completely offset by 
filtering processes in Outer East. Such a pattern would fit a previous observation of increasing socio-spatial polarisation at the neighbourhood level (Wessel, 2015).

Our findings interface with a broader discussion of housing and welfare-state policies. The well-known image of housing as the 'wobbly pillar' of the welfare state (Torgersen, 1987) is particularly relevant here, since it built on Norwegian experiences. A key feature of the image is that housing, viewed as a welfare sector, lacks many of the characteristics that guide successful welfare provision. Norms and standards are often unclear; professionals are often recruited from other fields; institutional complexes are often fragile; and practitioners tend to lack esprit de corps. All of these deviations have become more pronounced in the Norwegian case, e.g. through reduction in public expenditures, decentralisation of responsibilities and increasing reliance on market mechanisms (Stams $\varnothing, 2009)$. What our study brings to the fore is the massive importance of settlement patterns and urbanisation. The privatised housing system has fewer social conseqences in smaller places and medium-sized cities (Wessel, 1999), e.g. because population trends keep house prices from escalating ahead of incomes, or because individual self-provision remains a viable option. Disadvantaged households in Oslo and other major cities face a sharply different situation, with inelastic housing supply and limited mobility routes. Most of these households cannot engage in selfprovision, nor can they bank on family resources.

Currently, there is no geographic sensitivity in housing policies. The tenure structure is basically the same everwhere, and government programmes entail uniform financial products across rural, peri-urban and urban municipalities. It is a model that, despite substatitial success at the national level, fails to acknowledge the lack of efficiency in metropolitan housing markets. The key to a better framework, as we see it, is to increase and improve opportunities in the rental sector. This task may require some adjustments in the rental act, but the main job is to change the agency structure. There is a need for more non-profit making 
landlords, and for profit-making landlords who rent to long-term tenants. It is, of course, notoriously difficult to obtain such changes in a housing regime that was initiated before World War II (Bengtsson \& Ruonanavaara, 2010). It cannot be done in the short term, and has to be co-ordinated with changes in tax policies. A gradual movement towards financial neutrality between tenures is a prequisite for system-level improvements. Meanwhile, one should not neglect some options that exist in the current system. One alternative is to extend and improve the starter mortgage programme (Aarland \& Reid, 2018); another one is to develop housing schemes that allow flexible transition from tenancy to ownership. A pilot project in the co-operative sector represents a promising avenue: young households receive rental contracts for 3-5 years, and may then buy the dwelling on favourable terms (The building society TOBB, 2018). It is an initiative that resonates with practices and emotions in Norwegian housing policy. We believe, at the same time, that certain ingrained ideas need to be challenged. In particular, there should be no acceptance of the view that homeownership is the 'badge of citizenship'.

Our final comment concerns methodology. Despite some issues, such as the lack of a micro-economic basis (Nordvik, 2004), we do believe vacancy chain models hold significant potential for policy-related analysis. One advantage lies in the holistic approach, which allows a sound understanding of the constituent parts of a larger system (Magnusson, 1994; Ferrari, 2011). The ability to show interactions within the system increases the utility of such knowledge in planning, as an alternative to the crude 'numbers game' that tends to guide market assessments at local and regional levels (Ferrari et al., 2011). A second advantage is the possibility to incorporate distributive aspects. The broad shift from comprehensive to selective tools in the housing sector (Bengtsson \& Ruonavaara, 2010; Scwartz \& Seabroke, 2008) has left vulnerable groups at the mercy of market dynamics. If housing markets work effectively, without extensive failures, one may certainly expose effects on low-income 
groups through traditional analyses of supply and welfare gains. However, if housing markets fail, as we know they do (Maclennan, 2012), it might be better to use a vacancy chain approach. Such work has raised serious doubt about filtering policy in the United States (Galster, 1996; Marullo, 1985; Rosenthal, 2014). It is time to renew this tradition, in response to the diffusion of filtering policies.

\section{References}

Aarland, K., \& Reid, C. K. (2018). Homeownership and residential stability: does tenure really make a difference? International Journal of Housing Policy. Advanced online publication. http://www.tandfonline.com/doi/full/10.1080/19491247.2017.1397927

Andersson, R., \& Turner, L. M. (2014). Segregation, gentrification, and residualisation: from public housing to market-driven housing allocation in inner city Stockholm. International Journal of Housing Policy, 14(1), 3-29.

Barlindhaug, R. (2017). Boligmarked og flytting - betydning for segregasjon [The housing market and mobility - impact on segregation]. In J. Ljunggren (Ed.) Oslo - ulikhetenes by (pp. 121-144). Oslo: Cappelen Damm.

Bengtsson, B., \& Ruonavaara, H. (2010). Introduction to the Special Issue: Path Dependence in Housing. Housing, Theory and Society, 27(3), 193-203.

Bysveen, T., \& Knutsen, S. (1987). Vacancy chains initiated by out-migration. A study of the housing market in Oslo. Housing Studies, 2(3), 203-212.

Bø, E. E. (2015). Taxation of housing. Killing more than one bird with one stone. Statistics Norway: Discussion Paper 829.

Clark, E. (1984). Housing policies and new construction. A study of chains of moves in Southwest Skåne. Scandinavian Housing and Planning Research, 1(1), 3-14.

Chase, I. D. (1991). Vacancy chains. Annual review of sociology, 17, 133-154.

Chetty, R., Hendren, N., Kline, P., Saez, E., \& Turner, N. (2014). Is the United States Still a Land of Opportunity? Recent Trends in Intergenerational Mobility. American Economic Review, 104(5), 141-147.

Clapham, D. (2005). The meaning of housing. A pathway approach. Bristol: Policy Press.

Emmi, P. C., \& Magnusson, L. (1994). The predictive accuracy of residential vacancy chain models. Urban Studies, 31(7), 1117-1131.

Emmi, P. C., \& Magnusson, L. (1995). Opportunity and mobility in urban housing markets. Progress in planning, 1(43), 1-88. 
Ferrari, E. (2011). Conceptualising Social Housing within the Wider Housing Market: A Vacancy Chain Model. Housing Studies, 26(1), 95-116.

Ferrari, E., Leahy Laughlin, D. \& Watkins, C. (2011). Planning and the housing market: reflections on strategic housing market assessment in England. Town Planning Review 82(4), 393-423.

Galster, G. (1996). William Grigsby and the analysis of housing sub-markets and filtering. Urban Studies, 33(10), 1797-1805.

Galster, G., \& Sharkey, P. (2017). Spatial Foundations of Inequality: A Conceptual Model and Empirical Overview. RSF: The Russel Sage Foundation Journal of the Social Sciences, 3(2), 1-33.

Gulbrandsen, L., \& Langsether, A. (2003). Family transactions in the Norwegian housing market. Housing, Theory and Society, 20(3), 137-152.

Gullestad, M. (1989). Kultur og hverdagsliv. På sporet av det moderne Norge [Culture and everyday life. On the track of modern Norway]. Oslo: Universitetsforlaget.

Harrison, R. J. (1988). Opportunity models: adapting vacancy models to national occupational structures. Research in Social Stratification and Mobility, 7, 3-33.

Hua, C. I. (1989). Linking a housing vacancy chain model and a behavioral choice model for improved housing policy evaluation. The Annals of Regional Science, 23(3), 203-211.

Juvkam, D. (2000). Faktiske og potensielle pendlingsregioner [Actual and potential commuting regions]. Oslo: NIBR-notat 2000:130.

Lévy, J.-P., Boisard, O., \& Salingue, J. (2016). The ASHA model: An alternative to the Markovian approach to housing vacancy chains: An application to the study of population in Lille (Nord, France). Urban Studies, 54(11), 2248-2471.

Kauko, T. (2003). On current neural network applications involving spatial modelling of property prices. Journal of Housing and the Built Environment, 18(2), 159-181.

Maclennan, D. (2012). Understanding Housing Markets: Real Progress or Stalled Agendas? In D. F. Clapham, W. A. V. Clark, \& K. Gibb (Eds.) The Sage Handbook of Housing Studies. (pp. 5-26). London: Sage.

Magnusson, L. (1994). Omflyttning på den svenska bostadsmarknaden. En studie av vakanskedjemodeller [Residential Mobility on the Swedish Housing Market. A Study Using Vacancy Chain Models]. Uppsala: Geografiska Regionstudier 27.

Marullo, S. (1985). Housing opportunities and vacancy chains. Urban Affairs Quarterly, 20(3), 364-388.

Meen, D., \& Meen, G. (2003). Social Behaviour as a Basis for Modelling the Urban Housing Market: A Review. Urban Studies, 40(5/6), 917-935.

Murie, A., \& Musterd, S. (2004). Social exclusion and opportunity structures in European cities and neighbourhoods. Urban Studies, 41(8), 1423-1439.

Nordvik, V. (2004). Vacancy chain models: do they fit into the economist's toolbox? Housing, Theory and Society, 21(4), 155-162. 
Nordvik, V., \& Osland, L. (2017). Putting a price on your neighbour. Journal of Housing and the Built Environment, 32(1), 157-175.

OECD (2018) OECD Data: general government spending. Avaialable at https://data.oecd.org/gga/general-government-spending.htm (accessed January 10, 2018).

Ratcliff, R. U. (1949). Urban Land Economics. New York: McGraw Hill.

Rosenthal, S. S. (2014). Are private markets and filtering a viable source of low-income housing? Estimates from a 'repeat income' model. The American Economic Review, 104(2), 687-706.

Sampson, R. J. (2013). The place of context: a theory and strategy for criminology's hard problems. Criminology, 51(1), 1-31.

Scruggs, L., Jahn, D., \& Kuitto, K. (2014). Comparative welfare entitlements dataset 2. Version 2014-03. University of Connecticut \& University of Greifswald.

Sharkey, P. (2016). Neighborhoods, Cities, and Economic Mobility. RSF: The Russel Sage Foundation Journal of the Social Sciences, 2(2), 159-177.

Sharkey, P., \& Faber, J. W. (2014). Where, When, Why, and For Whom Do Residential Contexts Matter? Moving Away from the Dichotomous Understanding of Neighborhood Effects. Annual Review of Sociology, 40, 559-579.

Schwartz, H. \& Seabroke, L. (2008). Varieties of Residential Capitalism in the International Political Economy: Old Welfare States and the New Politics of Housing. Comparative European Politics 6, 237-261.

Skaburskis, A. (2006). Filtering, city change and the supply of low-priced housing in Canada. Urban Studies, 43(3), 533-558.

Smith, S., Munro, J., \& Chistie, H. (2006). Performing (housing) markets. Urban Studies, 43(1), 81-98.

Spilerman, S. (1972). The analysis of mobility processes by the introduction of independent variables into a Markov chain. American Sociological Review, 37, 277-294.

Sørvoll, J. (2011). Norsk boligpolitikk i forandring 1970-2010: dokumentasjon og debatt [Norwegian housing policy in change 1970-2010. Documentation and debate]. Oslo: NOVA Rapport 16/2011.

Stams $\varnothing$, M. A. (2009). Housing and the Welfare State in Norway. Scandinavian Political Studies, 32(2), 195-220.

Statistics Norway (2018a). Statbank, table 11038.

Statistics Norway (2018b). Statbank, table 06946.

Statistics Norway (2018c). Statbank, table 04695.

Statistics Norway (2018d). Statbank, table 03364.

Statistics Norway (2018e). Statbank, table 07230.

Tammaru, T., van Ham, M., Marcińczak, S., \& Musterd, S. (2015). Socio-Economic Segregation in European Capital Cities: East Meets West. London: Routledge. 
The Ministry of Finance (2013). Statsbudsjettet 2013 [The national budget 2013]. Available at https://www.statsbudsjettet.no/Statsbudsjettet-2013/ (accessed January 10, 2018).

The Ministry of Local Government and Regional Development (2013). Byggje - bu - leve. Ein bustadspolitikk for den einskilde, samfunnet og framtidige generasjonar [Building residing - living. A housing policy for the individual, the society and the future generations]. Avaialble at https://www.regjeringen.no/no/dokument/id2000006/ (accessed January 10, 2018).

The building society TOBB (2018). Leie-før-eie [Rent to buy]. Available at https://tobb.no/leieforeie (accessed 30 January 2018).

The Norwegian State Housing Bank (2011). Arsrapport 2011 [Annual report for 2011]. Available at https://www.husbanken.no/om-husbanken/aarsrapporter/ (accessed September 10, 2017).

Torgersen, U. (1987). Housing: the 'Wobbly Pillar' under the Welfare State. In B. Turner, J. Kemeny \& L. Lundqvist (Eds.) Between State and Market: Housing in the PostIndustrial Era (pp. 116-126). Stockholm: Wiksell.

Turner, L. M. (2008). Who gets what and why? Vacancy chains in Stockholm's housing market. European Journal of Housing Policy, 8(1), 1-19.

Watkins, C. A. (2001) The definition and identification of housing submarkets. Environment and Planning A 33(12), 2235-2253.

Wessel, T. (1999). Housing and welfare in Norway: compensation or double deprivation? Norwegian Journal of Geography 52(3), 209-219.

Wessel, T. (2015). Economic segregation in Oslo: polarisation as a contingent outcome. In T. Tammaru, S. Marcinczak, S., M. van Ham \& S. Musterd (Eds.) Socio-Economic Segregation in European Capital Cities: East Meets West (pp.132-156). London: Routledge.

Wessel, T., Turner, L. M., \& Nordvik, V. (2018). Population dynamics and ethnic geographies in Oslo: impact of migration and natural demographic change on ethnic composition and segregation. Journal of Housing and the Built Environment, 32. Advanced online publication. https://link.springer.com/article/10.1007/s10901-0179589-7.

White, H. C. (1970). Chains of opportunity. Cambridge: Harvard University Press.

White, H. C. (1971). Multipliers, vacancy chains, and filtering in housing. Journal of the American Institute of Planners, 37(2), 88-94. 


\section{Notes}

${ }^{\mathrm{i}}$ Housing filtering has persisted as a concept in urban studies for around 80 years. A classic definition states that filtering is the "changing of occupancy as the housing that is occupied by one income group becomes available to the next lower income group as a result of decline in market price, i.e. in sales price or rent value" (Ratcliff, 1949, p. 321).

ii Rights of first refusal entitled members of co-operative associations to purchase a dwelling on the same terms as those offered to a third party. This arrangement bolstered the price ceiling, since it broke the direct connection between sellers and buyers.

iii This bank dates back to 1946, and has provided construction loans for a large share of the Norwegian housing stock. Currently, the most important role is to handle housing grants, starter loans and housing allowances.

${ }^{\text {iv }}$ Adding attributes increases the problem of sparse cell counts.

${ }^{v}$ One criticism of previous studies based on census data has been loss of detail for moves occurring between census dates (Ferrari, 2011).

${ }^{v i}$ We had to choose between a rich analysis based on combined data and a fresher but cruder analysis based on register data alone. The year 2011 is representative for a long period of time. Annual house-price growth for single-family dwellings is a case in point. The growth was 4.5 per cent in 2011 , and 5.5 per cent over the period 2000 to 2017 (Statistics Norway, 2018d).

${ }^{7}$ These estimates are based on the total number of transfers and the tenure composition in 2011.

${ }^{8}$ Poor nest-leavers make up 56 per cent of all poor recruits in owner-occupied markets (detailed statistics for nest-leavers and other recruits is available upon request). 